\title{
Relations of Intellectual Capital Components in Hotel Companies
}

\author{
Article history: \\ Received: 21 December 2016 \\ Sent for revision: 17 January 2017 \\ Received in revised form: 26 March 2017 \\ Accepted: 13 April 2017 \\ Available online: 1 July 2017
}

Abstract: As an invisible asset within a company, in achieving the impact on business processes, intellectual capital uses its three components - human capital, structural capital and relational capital. The aim of the paper is to examine the interdependence between the aforementioned intellectual capital components. The research combines factor analysis and structural equation modelling on a sample of 44 hotel companies in Serbia. The results indicate the presence of a strong and positive relationship between the observed IC components. The strongest relationship is observed between relational capital and structural capital. Factor analysis confirmes grouping of the defined criteria around three factors - human, structural and relational capital.

Key words: intellectual capital, human capital, structural capital, relational capital, hotels

\section{Relacije komponenata intelektualnog kapitala u hotelskim preduzećima}

Abstrakt: Intelektualni kapital, kao nevidljiva imovina u preduzeću, uticaj na poslovne procese ostvaruje preko svojih komponenata - ljudskog, strukturnog i relacionog kapitala. Cilj rada je da se ispita jačina veze između navedenih komponenta intelekutalnog kapitala. Istraživanje kombinuje faktorsku analizu i jednačinu strukturnog modelovanja na uzorku veličine 44 hotelska preduzeća u Srbiji. Rezultati ukazuju na prisustvo jake $i$ pozitivne veze između posmatranih komponenti intelektualnog kapitala. Najjača veza prisutna je

\footnotetext{
${ }^{1}$ University of Kragujevac, Faculty of Hotel Management and Tourism in Vrnjačka Banja, Serbia, jasmina.lukic@kg.ac.rs
} 
Ognjanović J.: Relations of Intellectual Capital Components in Hotel Companies

između relacionog $i$ strukturnog kapitala. Faktorskom analizom potvrđeno je okupljanje definisanih merila oko tri faktora - ljudskog, strukturnog $i$ relacionog kapitala.

Ključne reči: intelektualni kapital, ljudski kapital, strukturni kapital, relacioni kapital, hoteli

\section{Introduction}

Intellectual capital represents "an asset that has no physical form, but creates value for the company" (Bontis, Keow, \& Richardson, 2000:387). Intellectual capital or IC achieves the impact on company operations through its components: human capital (HC), structural capital (SC) and relational capital $(\mathrm{RC})$. Thus, survival in market competition and long-term development of hotel companies is ensured by constant investment in IC components and their efficient use.

Service companies are becoming more productive in developed industrial countries. As a consequence, it can be said that we live in an economy based on services (Kianto, Hurmelinna-Laukkanen, \& Ritala, 2010). Hotel management is one of these service industries, and it is one of the highly profitable service industries in developed economies. The development of hotel industry is based on different types of knowledge - that of consumers' needs, the ways of creating services and methods of their differentiation. Since knowledge is the main component of both $\mathrm{HC}$ and intellectual capital, intellectual property in hotel industry becomes more important than tangible assets. This is supported by the fact that hotel management is a labour intensive industry and that performance largely depends on the employees' knowledge and skills. The other two IC components, SC and RC, which support the operation of $\mathrm{HC}$, also participate in the process of service design. In this way, the consumers' perception of the value and their choice are highly influenced by the knowledge and skills of employees (whose work is supported by intangible infrastructure), cooperation with consumers and the built brand, which makes the role of intellectual property in service creation of utmost importance. Therefore, hotel managers, in addition to preparing and monitoring financial statements, are also obliged to measure and report on the value of IC and its impact on the increase in companies' performance (Laing, Dunn, \& Hughes-Lucas, 2010).

Unlike the highly developed economies, where hotel industry is a highly profitable one, in Serbia this branch is still developing. The accommodation and food services sector employs 23,136 employees, accounting for $2.3 \%$ of the total number of employees in the Republic of Serbia. The share of this 
sector in the structure of VAT amounts to $1.1 \%$, while its share in the turnover realised in the Republic of Serbia amounts to $0.6 \%$ (Statistical Yearbook of the Republic of Serbia, 2015: 205). These indicators point to the underdevelopment of this sector and the need to create an adequate climate and develop infrastructure in a way that would enable its growth.

IC contribution is observed through three components: human, structural and relational capital, which are measured against appropriate criteria. Employees, with their knowledge and experience (human capital), supported by proper business tools for knowledge use (structural capital) and the existing market reputation (relational capital), directly take part in the creation of hotel services. The aim of the paper is to examine the interdependence among these IC components. The research is expected to show whether the IC components are present in hotels in Serbia, to point to the degree of their presence and examine how effectively they are used in the creation of hotel services. The aim of the paper also refers to the identification of the components which most dramatically affect $\mathrm{HC}, \mathrm{SC}$ and RC.

The primary contribution of the current research to the existing literature lies in application of the original model for examining the relationships between the IC components in hotels in Serbia. Secondly, on the basis of the undertaken research, the correlations between the variables of $\mathrm{HC}, \mathrm{SC}$ and $\mathrm{RC}$ of the observed hotels in Serbia are identified. Thirdly, using data processing, the criteria of IC components that affect their value are identified. Lastly, the undertaken research is based on the criteria of IC that have not been used by local authors so far.

The first part of the paper presents an overview of the previous research on the topic of importance of IC components in companies, with particular emphasis on the research related to the presence of these components in hotel companies. The second part of the paper, which defines the hypothesis, refers to the research methodology describing the sample and the used research instrument. The third part of the paper describes the applied statistical methods, and is followed by the results obtained on the basis of the processed data. In Conclusion, we underline the relationship among the observed IC components in the hotels in Serbia.

\section{Theorethical Background}

\subsection{Intellectual Capital Components}

IC is seen as the main driver of value creation within a company (Edvinsson, \& Malone, 1997; Stewart, 1997; Bontis, 1998) and represents the most 
valuable asset and the most powerful competitive weapon in corporate performance (Wang, \& Chang, 2005). Sim \& Koh (2001) believe that the company's ability to build its "intangible assets" or "intellectual capital" becomes a critical success factor in creating and sustaining competitive advantage. Steenkamp \& Kashyap (2010) claim that IC is a key element that determines the company's future earning potential, its growth and sustainability, and its ability to innovate, provide a better competitive position in the market and emphasise the knowledge that has an important role in creating economic power.

Intellectual property occupies the interest of managers with the advent of information era. Managers need the information on the IC value to define the corporate strategy and make quality decisions. Both tangible and intangible assets participate in the process of value creation and therefore, in addition to information on the degree of effective use of tangible assets, it is also necessary to provide information on the type and value of intellectual property used in the company. The information on the value and use of intellectual property has a greater practical value for managers in relation to the information on tangible assets, particularly in service sector industries.

IC operates through its components: human, structural and relational capital (Roos, \& Roos, 1997; Bontis, N. 1998).

Human capital represents the assets created by employees. Bontis, Dragonetti, Jacobsen, \& Roos, (1999) distinguish three categories of HC: the ability of employees (knowledge, skills, experience), intellectual agility (innovation, imitation) and attitude of employees (behaviour, motivation and ethics) (p.397). Therefore, it is the capital that is built by employing qualified employees, capital that is based on knowledge and whose growth is provided by constant training and professional development of employees (Ognjanovic, 2016). This further implies that high business performance also requires high labour force costs. Investing in HC leads to development of all other IC components and contributes to higher business performance. The value of $\mathrm{HC}$ can be calculated using the human capital efficiency (HCE) within the value added intellectual coefficient (VAIC) method. Rudez \& Mihalic (2007) measure the $\mathrm{HC}$ value using a questionnaire comprising the criteria of competence of employees, attitude of employees towards work and innovation of employees. The starting point for the preparation of the questionnaire in this research are the criteria of $\mathrm{HC}$ defined by Engstrom, Westnes \& Westnes (2003): the ability of employees, intellectual agility, performance, attitude and motivation of employees.

Structural capital is created by employees. It is owned by a company and its use creates a supportive business environment and infrastructure for employees. SC includes the results of knowledge use such as documents, 
databases, and processes and includes the company's intellectual property (patents, copyrights, trademarks) (Kianto, et. al., 2010). It is a component that represents the means the employees employ in the process of using knowledge for conducting business activities with the aim of providing greater business effectiveness and efficiency. Certain authors (Edvinsson, \& Malone, 1997; OECD, 1999) believe that SC, in addition to HC, is the main IC component. On the basis of the reviewed research, the $\mathrm{SC}$ value is calculated using the structural capital efficiency (SCE) or by means of a questionnaire. Using the latter, Rudez \& Mihalic (2007) measure the SC value on the basis of the following criteria: management psychology, culture, business process and information technology. On the other hand, in their research, Engstrom et. al. (2003) use the following criteria for measuring the SC value: efficiency and effectiveness, reconstruction and development, systems and procedures and atmosphere.

Relational capital refers to the way in which a company is accepted by the environment. It represents the company's ability to mutually cooperate with external stakeholders and thus use value and creative potential of $\mathrm{HC}$ and SC (Kianto, et. al., 2010). RC includes not only the relationships with customers that affect their satisfaction and loyalty, but also the cooperation with all participants in the value chain, from suppliers to consumers. Taking into account such RC range, Rudez \& Mihalic (2007) observe this type of capital through two components: end-customer-relationship capital and non-endcustomer-relationship capital. End-customer-relationship capital includes only the relationships with end users of hotel services, while non-end-customerrelationship capital includes the relationships with all other customers/partners. By nurturing RC, the company also nurtures its market reputation, which is of great importance in the information society. Chen, Cheng \& Hwang, (2005) express the value of RC through advertising costs. Engstrom, et. al. (2003) measure the value of RC with the help of a questionnaire, using the following criteria: loyalty and satisfaction of employees, market share, market orientation and customer management. These criteria are taken as the basis for preparation of the questionnaire used in the current paper for the assessment of RC.

Numerous authors accept the previously mentioned IC classification and base their research on it. In the remaining part of the subchapter, we give an overview of the obtained research results on the IC components relation.

Analysing the relationship among IC components, Bontis (1998) proves in his study that there is a medium correlation between $\mathrm{HC}$ and $\mathrm{SC}$ and $\mathrm{HC}$ and RC, while there is a small correlation between SC and RC. Bontis et. al. (2000) examine the relationships among IC elements of service and manufacturing companies. They conclude that there is a significant, strong and positive relationship between $\mathrm{HC}$ and $\mathrm{SC}$ and between $\mathrm{SC}$ and $\mathrm{RC}$ of the observed 
companies. It is also proven that there is a positive but not significant relationship between $\mathrm{HC}$ and $\mathrm{RC}$ of service companies, while this relation is statistically significant for manufacturing companies.

Bozbura (2004) examines the impact of IC on the performance of Turkish companies, through three components, human, organisational and relational capital, and proves a strong and positive correlation between $\mathrm{HC}$ and organisational capital and RC and organisational capital. Chen, Zhu \& Xie (2004) observe IC in the research process as a set of human, structural, innovative and customer capital. They prove a statistically significant, strong and positive relationship between the observed IC components. Tesng \& Goo (2005) undertake the research in Taiwan on the impact of IC on value creation in 500 most profitable manufacturing companies. They observe IC through four components: human, organisational, relational and innovative capital and prove that there is a positive correlation between the observed components. Cheng, Lin, Hsiao \& Lin (2010) base their research on a similar classification, observing IC through four components: innovative, process, human and customer capital. The results indicate a positive relationship of customer capital with other observed IC components. Bollen, Vergauwen \& Schneiders (2005) examine the relationship between IC components, intellectual property and performance of pharmaceutical companies in Germany, where they confirmed that IC components ( $\mathrm{HC}, \mathrm{SC}$ and $\mathrm{RC}$ ) are mutually correlated. Lee \& Guthrie (2010) analyse IC through HC, internal and external capital and conclude that there is a strong and positive correlation between $\mathrm{HC}$ and internal capital and internal and external capital, while the correlation between $\mathrm{HC}$ and external capital could be defined as a medium one.

IC components and their relation have also been analysed in the service sector. Lim \& Dallimore (2004) in their research conducted in Australia emphasise $\mathrm{HC}$ and $\mathrm{RC}$ as the most important IC components of service companies. Kianto et. al. (2010) research IC in manufacturing and service companies through four components, human, structural, relational and renewal capital. They conclude that $\mathrm{HC}$ and reconstruction capital are most important for service companies and suggest that, if companies want to move towards the creation of services, they have to change the IC management approach. The importance of $\mathrm{HC}$ in service companies is analysed by Namasivayam \& Denizci (2006), where they find out that human qualities, such as creativity and emotional intelligence of employees, have to be adequately valued since they affect the perceived value of service users. Demartini \& Paoloni (2011) analyse the impact of HC, as an IC component, in service companies, where they emphasise the importance of developing methods of measuring $\mathrm{HC}$ as a key factor of company management. 


\subsection{IC Components in Hotel Management}

Hospitality is a labour and capital intensive industry branch that involves a number of different activities, greater fluctuation of the volume of sales of services and lower profitability (DeFranco, \& Lattin, 2007, p. 8). Management of hotel operations is based on managing five departments (food and beverage, rooms, sales/marketing and reception), which make the production lines of a hotel (Brignall, Fitzgerald, Johnston, \& Silvestro, 1991, p. 235).

Results of the study by Harris \& Mongiello (2001) indicate that managers believe that hotel operations are sensitive to external environment to a large extent and that investment in $\mathrm{HR}$ and development of $\mathrm{HC}$ is of great importance for successful hotel performance. The importance of people (employees and guests) is also emphasised by Atkinson, \& Brown (2001), except that they suggest to hotel managers to pay special attention to the criteria that accompany the attitude of employees and satisfaction of guests.

Nolan (2002) points out that hotel industry is lagging behind compared to others, especially when it comes to relations between management and employees. In his opinion, it is the industry that is regressing in terms of professional approach to hotel management. In their study, Engstrom et. al. (2003) analyse the impact of IC elements on hotel business performance. They come to the conclusion that there is a statistically significant relationship between the IC components, whereby it is the strongest between $\mathrm{HC}$ and SC and it has the same intensity between $\mathrm{HC}$ and $\mathrm{RC}$ and $\mathrm{RC}$ and SC.

During 2003, Rudez \& Mihalic (2007) analysed the impact of IC dimensions on performance of 36 Slovenian hotels. The authors hold IC as the sum of four components: human and structural capital and two categories of relational capital - end-customer-relationship capital and non-end-customerrelationship capital. Based on the results of the correlation analysis, a strong and positive correlation between the observed four IC components is confirmed. The strongest level of the relationship is achieved between $\mathrm{HC}$ and SC. Walsh, Enz, \& Canina (2008) investigate the impact of IC on service companies performance, in the case of 538 hotels that implemented a generic strategy (low costs and differentiation). The authors analyse the impact of IC on hotel operations through the following components: system capital (functional knowledge), customer capital (brand and marketing knowledge) and human capital (knowledge of professional employees and employees who provide services). The results poin to the fact that the hotels implementing the low cost strategy by investing in system and customer capital can increase their performance. On the other hand, in order to provide higher performance, the hotels implementing the differentiation strategy have to invest in three observed IC components. 
Laing, Dunn, \& Hughes-Lucas (2010) undertook a research within two hotel chains in Australia in the period 2004-2007. IC is here observed through two components: $\mathrm{HC}$ and $\mathrm{SC}$ monitored through human capital efficiency (HCE) and structural capital efficiency (SCE). Both coefficients grow in the observed period and the authors conclude that $\mathrm{HC}$ and SC represent very significant assets of the observed hotels.

Bontis, Janoševic, \& Dženopoljac (2015) analyse the IC impact on financial performance of 34 hotels in Serbia in the period from 2009-2012. The obtained results show that there is a strong and positive relationship between $\mathrm{HC}$ and business profit and between $\mathrm{HC}$ and profitability. They also prove a strong relationship between SC and business profit and between SC and profitability of hotel operations. The findings point out that $\mathrm{HC}$ and $\mathrm{SC}$ have an impact on employee productivity and, to some extent, the profitability of Serbian hotels' operations.

Adeola (2016) deals with the analysis of the impact of $\mathrm{HC}$ on the development of hotel management in Nigeria. Emphasising the importance of $\mathrm{HC}$ for hotel management development, he believes that it is possible to achieve the improvement of $\mathrm{HC}$ by eliminating defficiencies in education development, eliminating social prejudice on vocational education, improving skills of hotel employees and gaining government support.

\section{Research Methodology}

\subsection{Sample Description and Data Collection}

In the present research, for collecting data on the IC categories, the survey method is employed. The database on the number, type and category of hotels operating in the Republic of Serbia is taken from the website of the Ministry of Trade, Tourism and Telecommunications of the Republic of Serbia. The questionnaire was sent to e-mail addresses of 358 hotels during March 2016. The respondents were managers of one-, two-, three-, four- and fivestar hotels, from the region of Vojvodina, Belgrade, Šumadija and Western Serbia, Southern and Eastern Serbia and Kosovo and Metohija. The sample size for the survey is 44 hotel companies. The response rate is $12.3 \%$, which is the usual response rate for the survey method.

The sample is dominated by three- $(41 \%)$ and four-star hotels (32\%) and then independent-type hotels (94\%). The largest number of surveyed managers is employed in hotels in the reagions of Šumadija and Western Serbia (32\%). 


\subsection{Research Instrument}

A questionnaire (survey), used as the research instrument, consists of two parts. The first part enquires about the general characteristics of hotels, and the second one measures the observed IC components (HC, SC and $\mathrm{RC}$ ). The total of 30 statements which comprise the questionnaire are measured using the summarised 5 point Likert scale, with 1 denoting strongly disagree and 5 denoting strongly agree. The questionnaire is modelled according to the surveys used in previously conducted research - Kianto et. al. (2010) and Engstrom et. al. (2003). Following the definition of $\mathrm{HC}$ (see Bontis et. al. 1999), the questionnaire includes the following HC criteria: Ability of employees, Intellectual agility and Behaviour and motivation of employees. As for SC (see Kianto et. al., 2010), it is measured through Efficiency and effectiveness, Internal databases, Systems and procedures and Atmosphere. RC, in accordance with its definition (see Kianto et. al., 2010), is monitored using the criteria of Loyalty and satisfaction of consumers, Market share, Cooperation with business partners and Handling customers.

Based on the research objective and defined variables, the following hypotheses are set (Fig. 1):

$\boldsymbol{H}_{1}$ : There is a strong and positive correlation between human and structural capital

$\boldsymbol{H}_{2}$ : There is a strong and positive correlation between human and relational capital

$\boldsymbol{H}_{3}$ : There is a strong and positive correlation between structural and relational capital

Figure 1 - Defined hypotheses

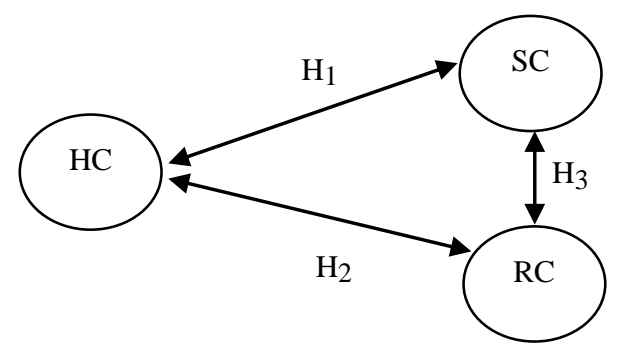




\subsection{Statistical Methods}

The collected data are subject of statistical analysis undertaken in three steps. First, the reliability analysis, measured by Cronbach's alpha coefficient, is applied. Then follows the confirmatory factor analysis which aims to confirm the grouping of the criteria around one factor. The third step has a twofold objective: to assess the fit of the model and to test the set hypotheses.

\section{Results and Discussion}

\subsection{Reliability Analysis}

Reliability and consistency of the criteria are measured through the Cronbach's alpha coefficient, whereby the values of this coefficient above 0.7 indicate a high reliability and consistency of the criteria (Nunnally, 1978). The value of the Cronbach's alpha of the entire model is 0.950 , which indicates a high reliability and consistency of the criteria. This result is only confirmed by the values of this coefficient observed for each criterion separately, which range from 0.942 to 0.948 .

\subsection{Factor Analysis}

The Factor Analysis is applied for the purpose of summing the observed criteria to a smaller number of factors. For the sake of the Confirmatory Factor Analysis, the paper employs the IBM SPSS Statistics statistical package for Social Sciences, Version 23. Applying this analysis confirms the grouping of the criteria around one factor. The analysis included three factors, i.e. HC, SC and RC. It points to the significance of the observed criteria for each of these three factors where the estimation is based on the factor weight values.

Table 1 shows the factor weight values for the observed three factors, whereby the minimum recommended factor weigh value amounts to 0.3 (Pallant, 2011, p. 190). The analysis confirmes that the proposed criteria are grouped around HC, SC and RC, whereby the factor weight values of the observed criteria are significantly higher than recommended. The application of the Confirmatory Factor Analysis shows that the selected criteria are significant for each observed factor ( $\mathrm{HC}, \mathrm{SC}$ and $\mathrm{RC}$ ) just as suggested by the authors of the previously conducted research (Kianto et. al., 2010 and Engstrom et. al., 2003). 
Ognjanović J.: Relations of Intellectual Capital Components in Hotel Companies

Table 1: Criteria and the observed factor weights

\begin{tabular}{|c|c|c|c|}
\hline \multirow[t]{2}{*}{ Criteria } & \multicolumn{3}{|c|}{$\begin{array}{l}\text { Factor } \\
\text { weights }\end{array}$} \\
\hline & 1 & 2 & 3 \\
\hline Ability of employees & 0.890 & & \\
\hline Intellectual agility & 0.852 & & \\
\hline Behaviour and motivation of employees & 0.888 & & \\
\hline Efficiency and effectiveness & & 0.642 & \\
\hline Internal databases & & 0.855 & \\
\hline Systems and procedures & & 0.880 & \\
\hline Atmosphere & & 0.765 & \\
\hline Guest loyalty and satisfaction & & & 0.776 \\
\hline Market share & & & 0.889 \\
\hline Cooperation with business partners & & & 0.853 \\
\hline Handling customers & & & 0.727 \\
\hline
\end{tabular}

\subsection{The Fit of the Model and Hypotheses Testing}

The applied Structural Equation Modeling is expected to explain the causal relationships between the observed IC components. The analysis is performed using the AMOS programme, with the use of Maximum Likelihood Assessment of the observed variables. The fit indices of the research model are within the acceptable limits (according to Hooper, Coughlan, \& Mullen, 2008). The value of chi-square $\left(\chi^{2}\right)$ amounts to 46.084 ; $p$ value is 0.270 , and the number of freedom degrees is 41 . In order to minimise the impact of the sample size, along with $\chi^{2}, \chi^{2} /$ df index is also shown. It amounts to 1.124 , which is less than the recommended upper limit of the value (this being 2). The NFI index amounts to 0.890 and is higher than the recommended minimum value of 0.8 , indicating good fit. With the aim of eliminating the impact of the sample size, the TLI index is shown, which amounts to 0.977 and whose value also indicates good model fit $(>0.8)$. The CFI index amounts to 0.986 while the value of the RMSEA index is 0.053 . Based on the obtained values of the fit indices, it can be said that the model is adaptable to a large extent.

The set hypotheses are tested by means of correlation coefficient. The obtained results are shown in Fig. 2. In relation to the values of the obtained correlation coefficients, the set hypotheses are found to be correct. The relationship between $\mathrm{HC}$ and $\mathrm{SC}$ is high and positive and amounts to 0.86 . Thus, $\mathrm{H}_{1}$ is confirmed. The positive and strong correlation between $\mathrm{HC}$ and $\mathrm{RC}$ (correlation coefficient amounts to 0.91 ) being confirmed, $\mathrm{H}_{2}$ becomes 
accepted. The highest level of correlation of 0.97 between SC and RC proves $\mathrm{H}_{3}$ to be true.

Figure 2: Path diagram with correlation coefficients

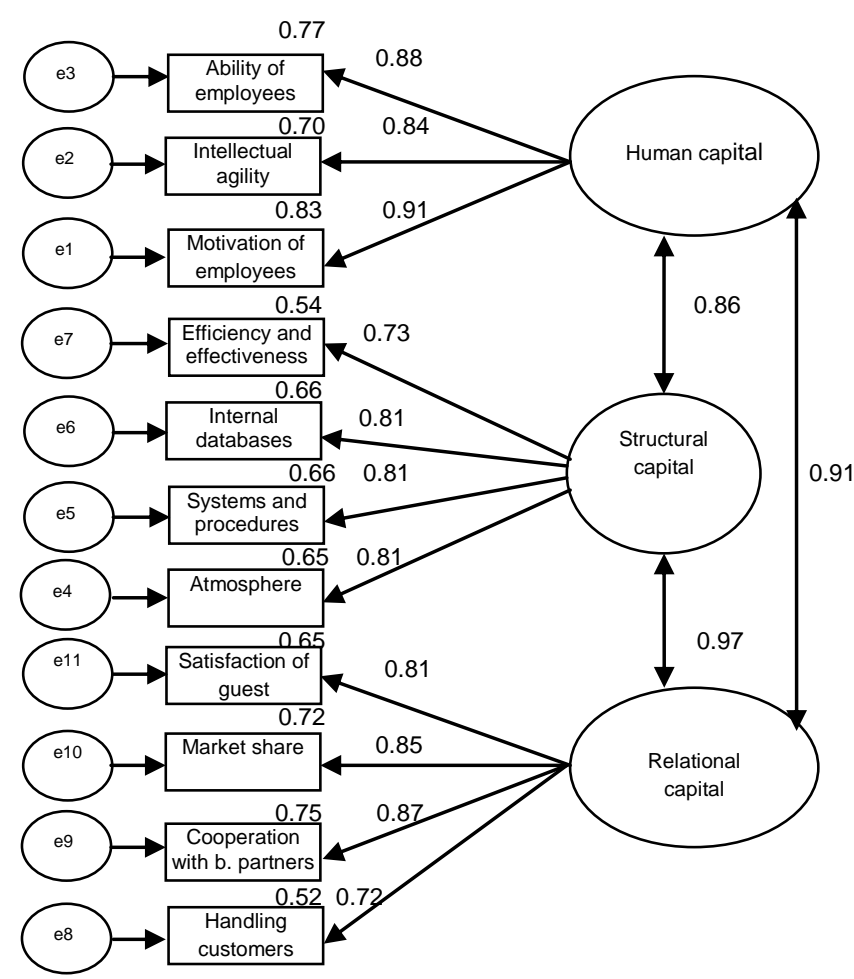

Based on the standardized regression weights of the variables, it is determined which of them has the greatest impact on the observed IC components. Due to the high values of this coefficient, the observed criteria have a high impact on $\mathrm{HC}, \mathrm{SC}$ and $\mathrm{RC}$ variables. Behaviour and motivation of employees has the greatest impact on the HC value. Internal databases, Systems and procedure and Atmosphere criteria have an equal impact on the SC value, while in the case of RC, the value is mostly influenced by Cooperation with business partners. The values of the squared multiple correlation coefficient are given in Table 2 and they describe the percentage of variance of $\mathrm{HC}, \mathrm{SC}$ and $\mathrm{RC}$ explained by the observed criteria. Behaviour and motivation of employees explains for $83 \%$ of the variance of $\mathrm{HC}$ while the rest is influenced by other factors. Internal databases explain for $66 \%$ of the variance of SC while the Cooperation with business partners explains for $75 \%$ of the $\mathrm{RC}$ variance. 
Ognjanović J.: Relations of Intellectual Capital Components in Hotel Companies

Table 2 - Values of squared multiple correlation coefficient

\begin{tabular}{|lc|}
\hline Criteria & $\begin{array}{c}\text { The value of squared multiple } \\
\text { correlation coefficient }\end{array}$ \\
\hline Ability of employees & 0.770 \\
\hline Intellectual agility & 0.703 \\
\hline Behaviour and motivation of employees & 0.828 \\
\hline Efficiency and effectiveness & 0.537 \\
\hline Internal databases & 0.663 \\
\hline Systems and procedures & 0.661 \\
\hline Atmosphere & 0.648 \\
\hline Guest loyalty and satisfaction & 0.652 \\
\hline Market share & 0.721 \\
\hline Cooperation with business partners & 0.751 \\
\hline Handling customers & 0.521 \\
\hline
\end{tabular}

\section{Conclusion}

IC is the main driver of value creation in a company, with combined use of its components - HC, SC and RC. The IC use would lead to positive results only with the simultaneous use of these three components. $\mathrm{HC}$ is the core of IC while $\mathrm{SC}$ and $\mathrm{RC}$ provide support to $\mathrm{HC}$ performance.

The reliability analysis proves a high consistency degree between the observed criteria. The confirmatory factor analysis confirmes the grouping of the defined criteria around three factors - HC, SC and RC. The assessment of model fit is analysed using the chi-square $\left(\chi^{2}\right), \chi^{2} / \mathrm{df}$ and the NFI, PNFI, CFI and RMSEA indexes, which indicates an excellent degree of fit of the observed research model. Data processing proves the presence of a strong and positive relationship between the IC components, which was also confirmed in the research by Engstrom et. al. (2003) and Bollen et. al. (2005). The relationship between $\mathrm{RC}$ and $\mathrm{SC}$ is confirmed to be the strongest one, which was also proved by Bozbura (2004).

Limitations of the research relate primarily to the sample size. Although the response rate $(12.3 \%)$ is quite small, it is common for data collection using the survey method. Credibility and reliability of the obtained results are higher when the sample is higher. Another limitation relates to the scarce number of hotels operating in Serbia (only 358) to which the questionnaire was sent. Small population reduces the possibility of forming a larger sample, since the usual questionnaire return rate is about $10 \%$. Finally, the third limitation relates to the disinterest of managers to participate in the survey although the 
results of studies of hotel business may be useful to managers (in planning and decision-making), owners, competitors and other stakeholders.

Managerial implications of the research can be expressed in two ways. First, based on the survey results, it is evident that IC components play an important role in the creation of hotel services. This means that managers need to consider in detail the value of capital components, which will motivate them to additional investment and better management in the future. Such an approach will have a positive impact on both business performance and image of a hotel. Second, the results clearly indicate which components of human, structural and relational capital determine their value in the highest degree. This further suggests that managers should pay more attention to the following components: the behavior and motivation of employees, internal database, systems and procedures, atmosphere and cooperation with business partners. It should also be mentioned that IC is an intangible asset which creates much greater value compared to tangible ones. The roles of IC components in the hotel business necessitates a more intensive use of these components and increase in their value.

Future research could be based on the extended criteria of HC, SC and RC values. Also, it would be useful to compare these research results with the results of the research in which the values of $\mathrm{HC}, \mathrm{SC}$ and $\mathrm{RC}$ are obtained on the bases of the volume of financial statement items. Another trend of the future research could be based on analysing a larger number of IC components (human capital, structural capital, relational capital, innovative capital, end-customer-relationship capital, non-end-customer-relationship capital, etc.), as well as analysing their impact on the IC value and company's business performance.

\section{References}

Adeola, O.A. (2016). Human capital development in the hospitality industry in Nigeria. Worldwide Hospitality and Tourism Themes, 8(2), 182-194. doi:10.1108/WHATT-11-2015-0053.

Atkinson, H., \& Brown, J. (2001). Rethinking performance measures: Assessing progress in UK hotels. International Journal of Contemporary Hospitality Management, 13(3), 128-136. doi:10.1108/09596110110388918.

Bollen, L., Vergauwen, P., \& Schneiders, S. (2005). Linking intellectual capital and intellectual property to company performance. Management Decision, 43(9), 1161-1185. doi:10.1108/00251740510626254.

Bontis, N. (1998). Intellectual capital: An exploratory study that develops measures and models. Management Decision, 36(2), 63-76. doi:10.1108/00251749810204142. 
Bontis, N., Dragonetti, N., Jacobsen, K., \& Roos, G. (1999). he knowledge toolbox: A review of the tools available to measure and manage intangible resources. Eropean Management Journal, 17(4), 391-402.

Bontis, N., Janoševic, J., \& Dženopoljac, V. (2015). Intellectual capital in Serbia's hotel industry. International Journal of Contemporary Hospitality Management, 27(6), 1365-1384. doi:10.1108/IJCHM-12-2013-0541.

Bontis, N., Keow, W.C., \& Richardson, S. (2000). Intellectual capital and business peformance in Malaysian industries. Journal of Intellectual Capital, 1(1), 85-100. doi:10.1108/14691930010324188.

Bozbura, F.T. (2004). Measurement and application of intellectual capital in Turkey. The Learning Organization, 11(4/5), 357-367. doi:10.1108/09696470410538251.

Brignall, T.J., Fitzgerald, L., Johnston, R., \& Silvestro, R. (1991). Product costing in service organizations. Management Accounting Research, 2, 227-248.

Chen, J., Zhu, Z., \& Xie, H.Y. (2004). Measuring intellectual capital: A new model and empirical study. Journal of Intellectual Capital, 5(1), 195-212. doi:10.1108/00251749810204142.

Chen, M., Cheng, S., \& Hwang, Y. (2005). An empirical investigation of the relationship between intellectual capital and firms' market value and financial performance. Journal of Intellectual Capital, 6(2), 159-176. doi:10.1108/14691930510592771.

Cheng, M.Y., Lin, J., Hsiao, T., \& Lin, T.W. (2010). Invested resource, competitive intellectual capital, and corporate performance. Journal of Intellectual Capital, 11(4), 433-450. doi:10.1108/14691931011085623.

Defranco, A., \& Lattin, T. (2007). Hospitality Financial Management. Hoboken, N. J. US: John Wiley \& Sons..

Demartini, P., \& Paoloni, P. (2011). Assessing human capital in knowledge intensive business services. Measuring Business Excellence, 15(4), 16-26. doi:10.1108/13683041111184071.

Edvinsson, L., \& Malone, M. (1997). Intellectual Capital: Realizing your Company's True Value by Finding its Hidden Brainpower. New York: Harper Collins.

Engstrom, T., Westnes, P., \& Westnes, S.F. (2003). Evaluating intellectual capital in the hotel industry. Journal of Intellectual Capital, 4(3), 287-303. doi:10.1108/09596110110388918.

Harris, P., \& Mongiello, M. (2001). Key performance indicators in European hotel properties: General managers' choices and company profiles. International Journal of Contemporary Hospitality Management, 13(3), 120-128. doi:10.1108/09596110110388909.

Hooper, D., Coughlan, J., \& Mullen, M.R. (2008). Structural equation modelling: Guidelines for determining model fit. Electronic Journal of Business Research Methods, 6(1), 53-60.

Kianto, A., Hurmelinna-Laukkanen, P., \& Ritala, P. (2010). Intellectual capital in service and product-oriented companies. Journal of Intellectual Capital, 11(3), 305-325. doi:10.1108/14691931011064563.

Laing, G., Dunn, J., \& Hughes-Lucas, S. (2010). Applying the VAIC ${ }^{\mathrm{TM}}$ model to Australian hotels. Journal of Intellectual Capital, 11(3), 269-283. doi:10.1108/14691931011064545. 
Lee, L.L., \& Guthrie, J. (2010). Visualising and measuring intellectual capital in capital markets: A research method. Journal of Intellectual Capital, 11(1), 4-22. doi:10.1108/14691931011013307.

Lim, L., \& Dallimore, P. (2004). Intellectual capital: Management attitudes in service industries. Journal of Intellectual Capital, 5(1), 181-194. doi:10.1108/14691930410512996.

Namasivayam, K., \& Denizci, B. (2006). Human capital in service organizations: Identifying value drivers. Journal of Intellectual Capital, 7(3), 381-393. doi:10.1108/14691930610681465.

Nolan, C. (2002). Human resource development in the Irish hotel industry: Tthe case of the small firm. Journal of European Industrial Training, 26(2/3/4), 88-99. doi:10.1108/03090590210421969.

Nunnally, J.C. (1978). Introduction to Psychological Measurement. New York: McGraw-Hill.

Ognjanovic, J. (2016). Intellectual capital in hotel companies. In: First International Scientific Conference: Tourism in Function of Development of the Republic of Serbia, 2016-06-02. Vrnjačka Banja.430-447.

-Organisation for Economic Cooperation and Development (OECD). (1999). Guidelines and instructions for OECD Symposium. In: International Symposium Measuring Reporting Intellectual Capital: Experiences, Issues, and Prospects, Amsterdam. Paris: OECD. June.

Pallant, J. (2011). SPSS priručnik za preživljavanje. Beograd: Mikro knjiga.

Roos, G., \& Roos, J. (1997). Measuring your company's intellectual performance. Long Range Planning, 30(3), 413-426.

Rudež, H.N., \& Mihalic, T. (2007). Intellectual capital in the hotel industry: A case study from Slovenia. International Journal of Hospitality Management, 26(1), 188-199. doi:10.1016/j.ijhm.2005.11.002.

Sim, K.L., \& Koh, H.C. (2001). Balanced scorecard: A rising trend in strategic performance measurement. Measuring Business Excellence, 5(2), 18-27. doi:10.1108/13683040110397248.

Statistical Yearbook of the Republic of Serbia for 2015. (2015). Belgrade: Statistical Office of the Republic of Serbia. Retrieved from http://webrzs.stat.gov.rs/WebSite/userFiles/file/Aktuelnosti/StatGod2015.pdf

Steenkamp, N., \& Kashyap, V. (2010). Importance and contribution of intangible assets: SME managers perceptions. Journal of Intellectual Capital, 11(3), 368390. doi:10.1108/14691931011064590.

Stewart, T.A. (1997). Intellectual Capital: The New Wealth of Organisation. London: Nicholas Brealey.

Tseng, C., \& James, G.Y. (2005). Intellectual capital and corporate value in an emerging economy: Empirical study of Taiwanese manufacturers. $R$ and $D$ Management, 35(2), 187-201. doi:10.1111/j.1467-9310.2005.00382.x

Walsh, K., Enz, C., \& Canina, L. (2008). The impact of strategic orientation on intellectual capital investments in customer service firms. Journal of Service Research, 10(4), 300-317. doi:10.1177/1094670508314285.

Wang, W.Y., \& Chang, C.F. (2005). Intellectual capital and performance in causal models-evidence form the information technology industry in Taiwan. Journal of Intellectual Capital, 6(2), 222-236. doi:10.1108/14691930510592816. 